\title{
Colloquy
}

\section{THE SPY WHO CAME IN FROM THE SOUTH}

\author{
DARRYL LI \\ University of Chicago \\ (iD) https:/ / orcid.org/0000-0002-8041-1285
}

During the years I have spent talking to men who traveled to distant lands to carry out jihad, the specter of espionage unsurprisingly hung over many a conversation - and not only the recurring and entirely well-placed suspicions I faced as an anthropologist holding a U.S. passport. Names popped up of infiltrators sent by Western and Arab intelligence agencies, mysterious individuals with odd behaviors who would suddenly vanish. There was the story of the Egyptian who, after being mortally wounded in battle, confessed that he had originally been a double agent but on experiencing the righteousness of the cause had decided to be true to his cover after all. Many of these threads proved difficult to trace further or verify, which is why I was rather startled when Muhammad (not his real name, of course) in straightforward terms told me about having been a spy.

We met in a detention center for migrants outside Sarajevo, the capital of Bosnia and Herzegovina, and Muhammad was fighting his deportation to Algeria, the country of his birth, after having been labeled a threat to national security. His name had been all over the local newspapers, described as a notorious jihadist. Muhammad's own narration of his peregrinations, however, seemed more interesting. As the editors of this collection of essays remind us, security for some always 
means insecurity for others, and it would appear that this holds true even for some agents of these regimes. As an alleged jihadist, Muhammad was a danger to security; as a spy, he was an instrument of it. But the reality underlying both was his experience as a migrant, not unlike the refugees Diana Allan (2020) writes about or the smugglers in the stories proffered by Emrah Yıldız (2020) and Kali Rubaii (2020).

Back in Algeria, Muhammad had sympathized with the Islamic Salvation Front (better known by its French acronym, FIS), the opposition movement whose 1990 electoral victory led to a state crackdown that sparked a bloody civil war. Like many men of his generation, Muhammad emigrated. He found a job in construction in the northern Italian city of Parma, while also quietly collecting donations for the FIS from diasporic compatriots. One day, the Algerian embassy in Rome, acting on a tip from local authorities, called Muhammad in for a chat. He started giving up names of other FIS supporters.

In those years, while Muhammad was hoping to avoid the civil war in his homeland, another armed conflict was raging just across the Adriatic, in Bosnia. Muhammad used to bring food to Bosnian Muslim refugees in Parma and to visit a refugee center in nearby Bologna. It was there that he met a man who introduced him to a female relative-let's call her Azra — who was still in Bosnia. Muhammad and Azra began a courtship by telephone and with the end of the war, he made his way to join her-nearly all migration was headed in the opposite direction, so he had little trouble - and they got married. Muhammad worked for a few years on Azra's family farm in a small village known for the quality of its potatoes while trying to figure out how to move them both to Italy.

One day, Muhammad's family in Algeria told him that the government wanted to speak to him again. So he called the embassy in Rome-the closest Algerian state body — where he received a mission: to infiltrate a "jihadi village" in northeast Bosnia. It was populated mostly by veterans of the jihad in Bosnia and their families who took over the homes of ethnic Serbs and set up a Salafi commune outside the country's mainstream Islamic institutions. The Algerian defense attaché in Rome told Muhammad to find out if their Islamist compatriots living in Bosnia had any involvement with armed groups back home. If he refused to assist, Muhammad would not be allowed to renew his passport, without which any kind of legal travel would prove next to impossible.

By Muhammad's account and those of Azra and others I spoke to who lived in the village at the time, the assignment did not appear particularly dramatic. As an outsider who had not participated in the jihad, Muhammad found himself 
more or less shunned, leaving after three months. Moreover, the commune was already under intense surveillance due to the frenzied media speculation about its use for illicit training or other nefarious activities; NATO peacekeepers regularly patrolled the village. In contrast, the most contentious disputes that came up in my interviews had to do with domestic quarrels between spouses and whether satellite dishes should be allowed. By 2000, NATO had evicted nearly all the jihad veterans, scattering them throughout Bosnia (Li 2019, 125-29). Muhammad continued to send desultory reports back to Rome, and thence presumably to Algiers. In 2005, he got his new Algerian passport as a reward for his efforts.

The anthropology of securitization as a state-driven and often semi-privatized endeavor has frequently focused on those at the receiving end of governmental power: refugees, migrants, and other victims (De Genova and Peutz 2010). A smaller companion literature has followed police agents, bureaucrats, and others who labor in this domain (Feldman 2012). Spies constitute a particular brand of workers, one for obvious reasons more elusive to the ethnographic gaze. But they nevertheless prove central to processes of securitization and to broader fantasies of the state. How to attend to spies? What to make of them in our midst? What can we learn about the state from looking at how it deals with the labor of clandestine intelligence gathering?

Muhammad's story falls oddly between the three most prevalent ways of imagining the work of cloaks and daggers. There is intelligence as imperial fantasy, often depicted as a blood sport between great powers. There is intelligence as omnipotence over the global South through the casual coup d'état, as with the CIA in Guatemala, Iran, Chile, and elsewhere. And there is intelligence as secret police and surveillance, a form of domestic control shared by all modern states but particularly marked in authoritarian ones (Glaeser 2010; Masco 2017; Verdery 2018). The idea of one poor state (Algeria) sending spies far away to another (Bosnia) constitutes a peculiar kind of south-south exchange that does not fit readily into existing frameworks and popular imaginations. It is easier for Western cinematic audiences to imagine (and pine for) an Idris Elba cast as James Bond in Her Majesty's Secret Service than it is to conjure him as a heroic spy working for a formerly colonized state. ${ }^{1}$

How, then, does a poor state spy abroad? Muhammad suggests one answer: by exploiting its diaspora. This seems entirely unsurprising: while dominant representations of espionage presuppose highly centralized bureaucratic institutions walled off from society by various regimes of secrecy, this is historically the exception rather than the norm. The more common way to gather intelligence - a 
specialized term for information - has been simply to ask travelers moving back and forth across different societies and build up from there (Bayly 1996). For most spies today, diplomatic missions provide the sea in which they can swim, replete with immunity from local laws if caught. For Algeria, a country that lacks the resources to support an embassy in Bosnia, let alone an intelligence station, the diaspora makes for the best available human resource. The adage that long-term travelers from rich countries get to call themselves expats while the rest are mere migrants shapes the possibilities for espionage as well. Indeed, it is the Western super-spy — somehow crossing borders and navigating foreign cities without friction - that requires provincialization. There can be no James Bond without the missionaries, merchants, soldiers, and slave-dealers who in all likelihood would populate the Bond family tree.

As a transnational endeavor in an unequal world, espionage is also characterized by a hierarchical division of labor that does not fundamentally differ from what one finds in not-for-profits, journalism, or academic research. Muhammad's Algerian handlers likely hawked his reports to their counterparts in Italian or U.S. intelligence to prove their own worthiness for money, weapons, or other forms of aid. These are relationships that can still produce surprises and on occasion quite literally blow up in one's face. One of the deadliest incidents in CIA history came in 2009, when a Jordanian who had promised to infiltrate al-Qaeda instead detonated a suicide vest at an American base in Afghanistan. He had been initially recruited and managed by Jordanian intelligence, who were introducing him to their CIA partners for the first time. The bomber made sure that his handler-also a cousin to King Abdullah_-stood within the blast radius.

What all intelligence services, from countries rich or poor, share is a basic attitude of disposability toward their "assets." Muhammad learned this after returning to Algeria in 2007, bringing Azra and his children along, his job complete, and legal paperwork squared away. But what Allan (2020) calls the "spiral or whorl" of migrant lives — where even obtaining formal statuses like citizenship can shape insecurity as much as prevent it — only accelerated. Soon after his return, Muhammad began receiving phone calls from persons unknown to him threatening reprisals for his past spying. He fled to Italy, but was arrested and deported home again. Within months, warnings became reality as someone placed a bomb outside his house that scattered shrapnel throughout his body. Muhammad decided to resettle in Bosnia, with his family following yet again. By now, the combination of his race, religion, associations, and pattern of movements was suspicious on its own terms. When we met in 2010, he had been detained as one of the "usual suspects" after a 
bombing elsewhere in Bosnia. The next time I visited the detention center a year later, he was gone, long since deported.

\begin{abstract}
Dominant imaginaries of espionage presume that all states surveil their populations but that only the powerful ones can play the "great game" of spying outside their borders. How, then, does a poor postcolonial state spy abroad? Drawing on an ethnography of Arab migrants and jihad fighters in Bosnia and Herzegovina, this essay suggests one answer: powerful states have their spies pose as diplomats, while weak ones exploit their diasporas. This realization takes one step toward demystifying and de-exceptionalizing state intelligence apparatuses and understanding them as socially embedded institutions. [espionage; migration; security; labor]
\end{abstract}

\title{
NOTES
}

1. It is noteworthy that the closest thing to such a representation requires a fantasy of having never been colonized in the first place, namely, the kingdom of Wakanda in the film and comic book Black Panther. Even in that vision of a super-sovereign state of proud Black folks, the CIA is cast as a benign presence - at the expense of its actual history of undermining popular movements in Africa, as many a kill(monger)joy has pointed out.

\section{REFERENCES}

Allan, Diana

2020 "The Long Turning: A Palestinian Refugee in Belgium." Cultural Anthropology 35, no. 2: 225-30. https://doi.org/10.14506/ca35.2.05.

Bayly, C. A.

1996 Empire and Information: Intelligence Gathering and Social Communication in India, 1780-1870. Cambridge, UK: Cambridge University Press.

De Genova, Nicholas, and Nathalie Peutz, eds.

2010 The Deportation Regime: Sovereignty, Space, and the Freedom of Movement. Durham, N.C.: Duke University Press.

Feldman, Gregory

2012 The Migration Apparatus: Security, Labor, and Policymaking in the European Union.

Glaeser, Andreas Stanford, Calif.: Stanford University Press.

2010 Political Epistemics: The Secret Police, the Opposition, and the End of East German Socialism. Chicago: University of Chicago Press.

Li, Darryl

2019 The Universal Enemy: Jihad, Empire, and the Challenge of Solidarity. Stanford, Calif.: Stanford University Press.

Masco, Joseph

2017 "Boundless Informant': Insecurity in the Age of Ubiquitous Surveillance." Anthropological Theory 17, no. 3: 382-403. https://doi.org/10.1177/ 1463499617731178 .

Rubaii, Kali

2020 “Trust without Confidence: Moving Medicine with Dirty Hands." Cultural Anthropology 35, no. 2: 211-17. https://doi.org/10.14506/ca35.2.03.

Verdery, Katherine

2018 My Life as a Spy: Investigations in a Secret Police File. Durham, N.C.: Duke University Press. 
Yildız, Emrah

2020 "Nested In(securities): Commodity and Currency Circuits in an Iran under Sanctions." Cultural Anthropology 35, no. 2: 218-24. https://doi.org/10.14506/ ca35.2.04. 